\title{
Penyuluhan dan Pelatihan Pemasaran Desa Wisata Cikolelet dengan Teknik Covert Selling
}

\author{
Themmy Noval ${ }^{1}$, Lyly Soemarni ${ }^{2}$, Andi Guna ${ }^{3}$, Kezia Elsty $^{4}$, \\ Casey Eve ${ }^{5,}$ Nicholas $^{6}$, Naomi Michelle Lim $^{7}$ \\ Program Studi Pariwisata Universitas Pradita
}

themmy.noval@pradita.ac.id, lyly.soemarni@pradita.ac.id, andi.guna@pradita.ac.id,

\begin{abstract}
Abstrak
Sumber daya manusia dan ekonomi merupakan hal utama yang harus menjadi perhatian, melihat kondisi masyarakat Desa Wisata Cikolelet yang memiliki jumlah tamatan SMA yang masih minim dan kurangnya pengetahuan mengenai kegiatan kepariwisataan, dalam hal pemasaran desa wisata perlu dilakukan penguatan pendidikan dan kapasitas masyarakat lokal dimana masyarakat secara langsung dan bersama dapat membantu mengenalkan dan mempromosikan desanya. Kegiatan yang dilakukan sebagai upaya pengembangan kapasitas masyarakat desa berupa pelatihan untuk memberikan kemampuan dan peningkatan pengetahuan masyarakat lokal terkait pemasaran pariwisata dan penguatan ekonomi. Bentuk kegiatan yang dilakukan adalah penyuluhan dan pelatihan pemasaran desa wisata Cikolelet dengan teknik covert selling bagi masyarakat desa cikolelet khususnya warga yang berhubungan dengan kegiatan pariwisata. Peyuluhan dan pelatihan covert selling diajarkan kepada semua masyarakat desa terlebih mereka yang mempunyai usaha yang berhubungan dengan pariwisata desa, pelatihan covert selling mencakup teknik memahami kelebihan dan kekurangan dari desa kemudian menterjemahkan dalam kalimat dan gambar pemasaran yang bertujuan memperkenalkan desa. Peserta dan masyarakat secara aktif diberi pengetahuan untuk mengetahui kebutuhan teknik yang diperlukan oleh masing masing perserta. Kegiatan PkM ini mampu dilakukan oleh warga dan diaplikasikan sehari-hari untuk memacu semangat warga sebagai desa wisata dan untuk menjadi seorang wirausahawan yang berguna bagi perekonomian desa.
\end{abstract}

Kata Kunci: covert selling, pemasaran, cikolelet, wirausaha, wisata.

\section{PENDAHULUAN}

Pariwisata telah menjadi komponen yang semakin populer dari strategi pembangunan di banyak daerah terbelakang, dengan potensi pariwisata untuk meningkatkan ekonomi lokal dan mengurangi kemiskinan (Muganda et al., 2010). Pariwisata adalah sebuah industri yang di dalamnya terdapat komponen yang disebut $4 \mathrm{a}$, yaitu atraksi wisata, aksesbilitas, amenity atau fasilitas, dan ancillary atau organisasi yang mengurus kepariwisataan (Cooper dalam Prasiasa, 2013:52).

Pariwisata salah satu industri yang paling berpotensi untuk dikembangkan di Indonesia, mengingat semakin meningkatnya permintaan produk wisata di Indonesia dari tahun ke tahun. Peningkatan permintaan produk wisata di Indonesia dapat dilihat melalui tingkat kunjungan wisatawan yang terus meningkat dari tahun ke tahun. Kunjungan wisatawan seperti daerah provinsi Banten mengalami kenaikan yang signifikan seperti terlihat dari data BPS (2019) pada tahun 2017 sejumlah 9.551.703 menjadi 13.275.125 ditahun 2018. Trend peningkatan kunjungan wisatawan di Indonesia tersebut dipandang beberapa stakeholder pariwisata daerah sebagai peluang pasar yang sangat menjanjikan bagi pengembangan pariwisata. Salah satu bentuk wisata unggulan daerah yang saat ini sangat popular dikembangkan adalah desa wisata. 
Persoalan desa wisata dalam penangannya sangat bersifat lintas sektor, untuk mewujudkan desa wisata yang menghasilkan pembangunan yang berkelanjutan, adil dan merata untuk dirasakan oleh semua warga desanya diperlukan pembangunan dengan didukung peran aktif dan kerjasama secara terpadu dari seluruh stakeholder terkait. Salah satu desa wisata yang mulai aktif dikembangkan sejak 2015 adalah desa wisata Cikolelet di daerah Anyer Banten, di Desa Wisata Cikolelet hampir semua tempat wisata dapat diakses oleh wisatawan dan fasilitas yang tersedia pada area ini diantaranya : homestay (sebagai tempat penginapan wisatawan selama menginap di Desa Wisata Cikolelet), rumah penduduk untuk wisata kebudayaan maupun kerajinan (Sanggar kesenian/ Budaya), serta fasilitas fasilitas penunjang wisata lainnya terutama fasilitas wisata yang berada di masing-masing daya tarik wisata yang ada di Desa Wisata Cikolelet. Sebagai pendukung fasilitas ada juga zonasi yang berisi fasilitas-fasilitas pendukung kawasan terutama jika dikembangkan menjadi desa wisata, sedangkan untuk peningkatan kualitas dari kegiatan wisata di Desa Cikolelet ini dibuat toko-toko souvenir yang dapat menjual ciri khas lokal dari Desa Cikolelet.

Desa Cikolelet yang sebelumnya memiliki karakteristik dibawah standar untuk disebut sebagai sebuah desa wisata mulai berbenah dan merubah diri sesuai standar desa wisata. Hanya saja untuk mencapai karakter yang sesuai standar diperlukan enam indikator utama meliputi sumberdaya manusia (SDM), ekonomi, infrastruktur, kapasitas keuangan wilayah, aksesibilitas dan karakteristik daerah. Sumber daya manusia dan ekonomi merupakan hal utama yang harus menjadi perhatian, melihat kondisi masyarakat Desa Wisata Cikolelet yang memiliki jumlah tamatan SMA yang masih minim dan kurangnya pengetahuan mengenai kegiatan kepariwisataan, untuk menciptakan desa wisata yang berkelanjutan, perlu dilakukan penguatan pendidikan dan kapasitas masyarakat lokal guna meningkatkan kualitas pariwisata di Desa Wisata Cikolelet. Kegiatan yang dilakukan sebagai upaya pengembangan Desa Wisata Cikolelet berupa pelatihan untuk memberikan bekal kemampuan danpeningkatan pengetahuan masyarakat lokal terkait pariwisata dan penguatan ekonomi.

Pemberian bekal berupa pelatihan pemasaran desa dilakukan dengan penyuluhan tentang pentingnya memasarkan dan mencari pasar sasaran yang tepat untuk wisatawan desa wisata, diperlukan suatu kejelian dalam setiap tahun pemasaran teknik yang akan digunakan harus sesuai dengan tren dan sistem yang digunakan saat itu, saat ini teknik pemasaran yang tepat adalah dengan memasarkan melalui multimedia atau media sosial tetapi masyarakat desa cikolelet tidak mengerti lebih dalam cara pemanfaatannya, dalam pelatihan ini dikenalkan multimedia dan media sosial yang dapat digunakan, kemudiam diajarkan untuk menggunakan secara bijak dan professional.

Langkah yang terpenting adalah bagaimana mengisi platform aplikasi tersebut dengan cara pemasaran yang tepat, teknik covert selling yang biasanya digunakan untuk menjual barang dalam hal ini tangible digunakan untuk bidang pariwisata, pelatihan diikuti oleh beberapa pelaku pariwisata masyarakat desa dengan bidang usaha yang berbeda dan peserta diajarkan secara langsung bagaimana menggunakan dan melatih secara berkala supaya mampu dan terbiasa. Peserta diajak untuk langsung menuliskan praktek penggunaan covert selling dan secara bersama dibacakan serta diberi masukan mengenai kekurangan dan kelebihan dari hasil praktek tersebut

Peserta mengikuti semua tahapan dalam pelatihan sampai dengan selesai dan diharapkan peserta mau terus berlatih untuk penggunaan teknik covert selling pada pemasaran produk wisata desa cikolelet. Berikut adalah beberapa potensi yang dimiliki untuk dapat menggunakan teknik covert selling pariwisata Desa Cikolelet:

1) Sumber Daya

Desa Cikolelet mempunyai sumber daya alam dan kekayaan alam yang berlimpah diantaranya adalah:

a. Cikolelet dialiri oleh 2 aliran sungai besar sebelah utara Air Cigede dan sebelah selatan Sungai Cidanau, kedua aliran sungai tersebut adalah penyuplai air utuk irigasi pertanian dan perkebunan.

b. Pesona Alam

c. Hutan Rakyat dan Perkebunan

d. Pesawahan

e. Peternakan dan Perikanan

2) Ekonomi

a. Petanian, Peternakan dan Perikanan Pendidikan

866 

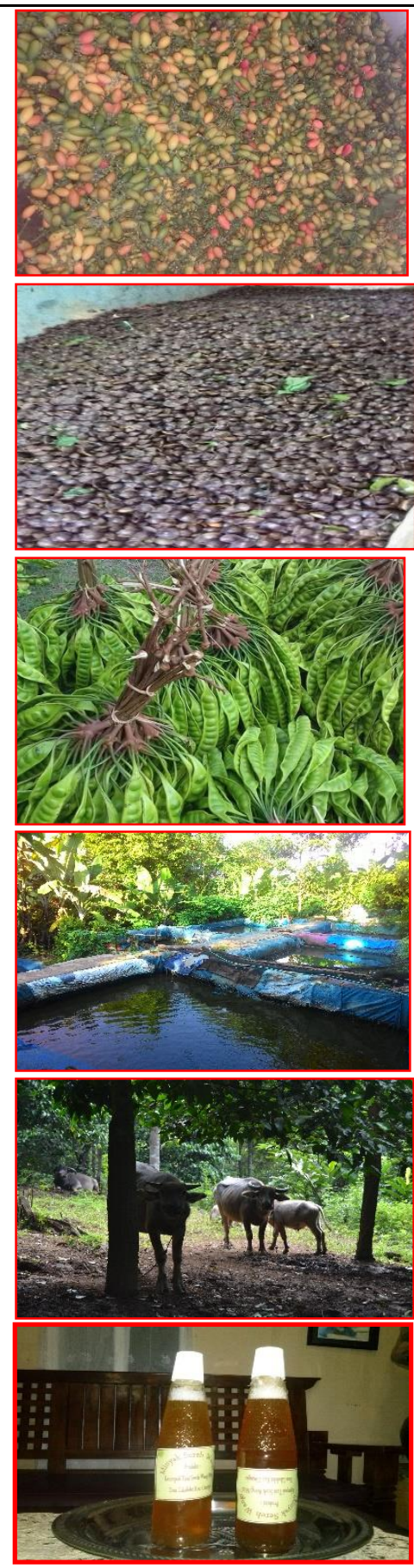

b. Usaha Kecil Menengah

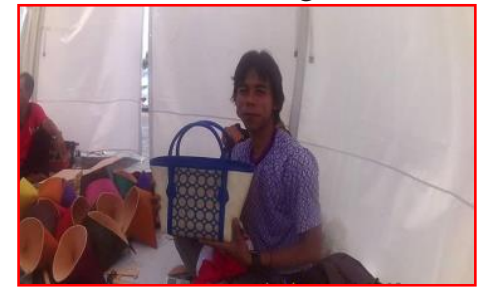

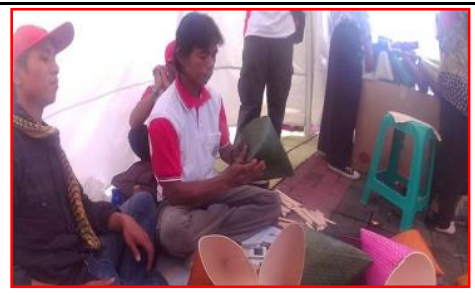

3) Seni Budaya

Desa Cikolelet mempunyai beragam Kesenian Tradisional dan Pesona alam pegunungan dan Air terjun yang Exsotik dan dapat dikembangkan untuk menjadi potensi Wisata di Desa Cikolelet.

a. Parade/Karnaval Seni Budaya

b. Ngarak/Ngiring Panganten

c. Ngagurah Dano

d. Marhabaan/Ngayun

e. Nukuh

f. Mamaca/Maca Syekh

g. Prah Prahan

4) Bidang Seni:
a. Seni Rudat
b. Rampak Qasidah
c. Kesenian Marawis
d. Kesenian Kendang Pencak Silat
e. Kesenian Calung

5) Obyek Wisata Alam
a. Wisata Alam Curug Lawang
b. Wisata Alam Curug Kembar
c. Wisata Alam Puncak Pilar
d. Wisata Alam Puncak Cibaja

Permasalahan yang dihadapi oleh masyarakat desa wisata Cikolelet sebagai berikut: 1) Mitra menjadi lebih teredukasi mengenai penggunaan media sosial dan cara pemasaran yang tepat secara teoritis dan prakteknya. 2) Mitra yang mengikuti penyuluhan dan pelatihan ini memiliki pengetahuan dan ketrampilan cara memasarkan produk pariwisata dengan Teknik covert selling. 3)Mitra memiliki pengetahuan dalam menentukan pasar dan sasaran dalam melakukan pemasaran sesuai dengan produk pariwisata yang dimiliki. 4) Mitra dapat mempraktekkan teknik covert selling dengan baik dan ikut membantu mitra lain yang mempunyai usaha berhubungan dengan pariwisata. 


\section{METODE}

Bentuk kegiatan yang dilakukan adalah penyuluhan dan pelatihan pemasaran desa wisata Cikolelet dengan teknik covert selling bagi masyarakat desa cikolelet khususnya kampung ataupun warga yang berhubungan dengan kegiatan pariwisata baik pariwisata produk utama maupun produk pendukung. Peyuluhan dan pelatihan covert selling ini dihadiri oleh para pemangku kepentingan juga diantaranya perangkat desa seperti pokdarwis Desa Cikolelet, pelatihan covert selling mencakup Teknik memahami kelebihan dan kekurangan serta cara mengatasinya sehingga menghasilkan suatu tulisan atau ajakan yang bersifat memasarkan. Jumlah peserta sebanyak 15 peserta dan diawali dengan doa dan tanya jawab untuk mengetahui kebutuhan Teknik yang diperlukan oleh masing masing perserta. Kegiatan dilakukan diruangan pertemuan serbaguna kantor desa cikolelet, dalam hal ini tidak ada bahan baku pelatihan yang dibagikan, hanya disediakan perangkat tulis dan kertas untuk mendukung pelatihan dan praktek dalam covert selling. Pemateri menyampaikan secara langsung materi yang dibawakan melalui layar projector dan peserta dapat bertanya setiap saat apabila masih belum mengerti mengenai penjelasan dari pemateri. Pelatihan dibantu oleh mahasiswa paradita prodi Pariwisata untuk dokumentasi, asisten computer dan penyediaan alat tulis.

\section{HASIL DAN PEMBAHASAN}

Kegiatan dilaksanakan pada hari Selasa, 03 Desember 2019 bertempat di ruang serbaguna kantor desa Cikolelet dengan judul kegiatan "Penyuluhan dan pelatihan pemasaran desa wisata cikolelet dengan teknik covert selling" berjalan dengan baik tanpa hambatan sedikitpun. Sasaran diadakannya kegiatan penyuluhan pemasaran convert selling adalah: 1) Mengajarkan kepada masyarakat desa wisata untuk mampu berdikari dengan memperkenalkan daerahnya melalui media yang mudah. 2) Pelaku pariwisata desa khususnya pengusaha yang berasal dari desa wisata mampu memperkenalkan produknya secara tepat dan benar dengan tujuan memperkenalkan desa wisata. 3) Menciptakan desa wisata yang berkelanjutan dengan mengatur arus wisatawan melalui proses pemasaran yang dilakukan.

Masyarakat yang berhubungan langsung dengan sektor pariwisata sangat antusias mengikuti kegiatan ini dan mereka belajar teknik covert selling. Masyarakat juga dengan mudah memahami materi pemasaran yang disampaikan karena sebagian dari peserta PKM adalah para pengelola usahanya langsung ataupun terlibat langsung dengan kegiatan pariwisatanya.

Materi dalam pelatihan dan penyuluhan dipaparkan dalam bentuk teori dan praktek, teori disampaikan secara langsung diutamakan terjalin komunikasi dua arah dengan masyarakat. Materi juga disampaiakn secara lisan dan detil, Masyarakat sangat antusias untuk mengaplikasikan hasil pelatihan ini dan melihat hasil yang akan didapat, masyarakat juga melakukan praktek langsung penulisan convert selling pemasaran desa wisata, masing masing pserta menggunakan alat bantu canggih berupa handphone yang dimiliki dengan mengandalkan internet, masyarakat berlatih langsung dengan menggunakan bidang usaha nya sebagai bahan dalam pelatihan penulisan convert selling. tetapi hasil kegiatan ini tidak dapat dilihat secara langsung karena membutuhkan waktu untuk berlatih menulis dan memahami setiap kalimat yang dibuat dan hasil akan terlihat dengan latihan yang terus menerus. Guna dapat memonitor hasil pelatihan yang dilakukan kami panitia khususnya pemakalah memberikan kesempatan kepada masyarakat untuk dapat berkonsultasi secara online diluar waktu makalah yang diberikan. Pelatihan ini juga pentiing untuk pemateri khususnya Pradita Universitas Program Studi Pariwisata dan dapat dilihat melalui form kuesioner yang dibagikan kepada peserta.

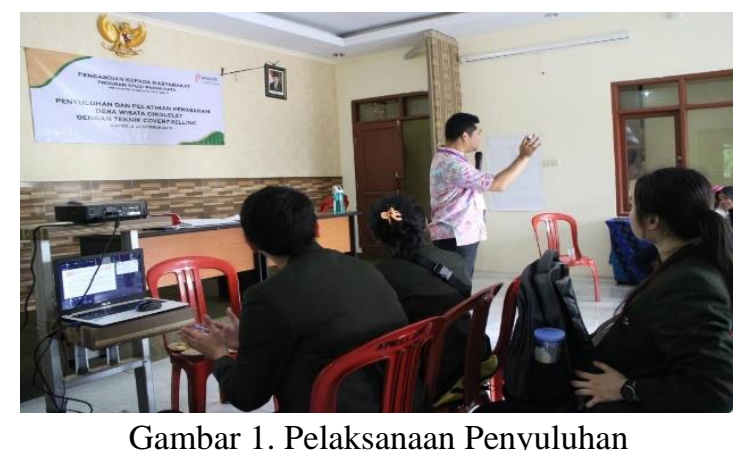

Pendidikan 


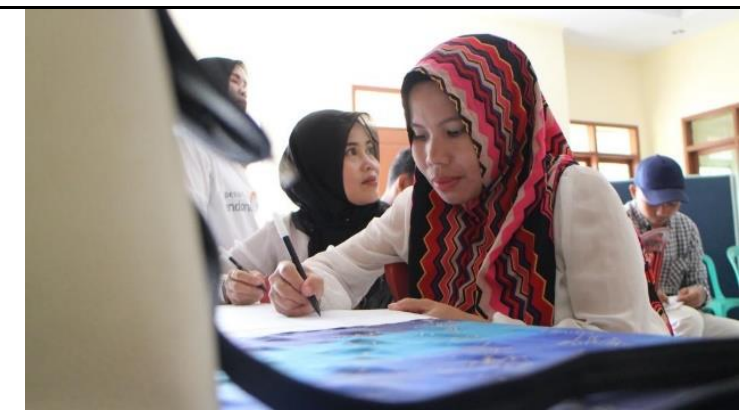

Gambar 2. Latihan Teknik Covert Selling

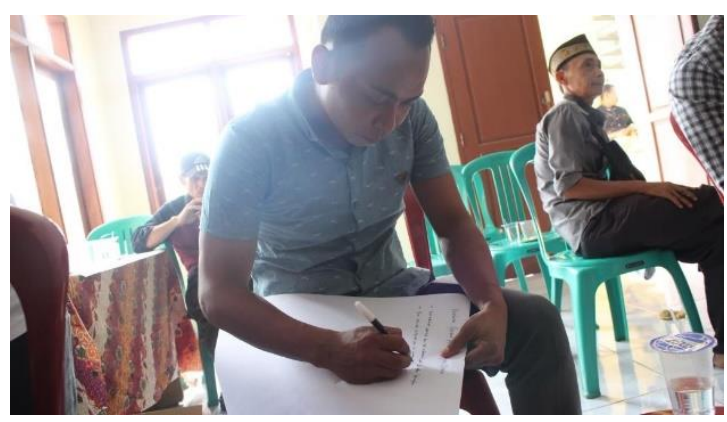

Gambar 3. Partisipasi peserta

\section{KESIMPULAN}

Terdapat beberapa rekomendasi setelah melakukan kegiatan pelatihan penyuluhan teknik convert selling:

1. Pelatihan teknik convert selling agar dilakukan beberapa kali dan terjadwal dengan baik oleh pemerintahan desa, sehingga masyarakat mampu menyerap pengetahuan pemasaran secara maksimal.

2. Pemerintah desa memberikan fasilitas berupa jaringan internet dibeberapa titik sehingga memudahkan masyarakat yang akan melakukan praktek penulisan teknik pemasaran.

3. Masyarakat harus diberikan edukasi tambahan dalam menggunakan internet dan media sosial supaya tidak keluar dalam koridor kesopanan dan etika dalam dunia maya

Manfaat bagi masyarakat dan pelaksana yang didapat dari pelaksanaan PkM:

1. Masyarakat mendapatkan pengetahuan baru bagaimana cara memahami kelebihan dan kekurangan dari produk wisata yang dihasilkan.

2. Mendapatkan pengetahuan dalam menterjemahkan suatu kalimat yang baik dan benar dalam hal pemasaran pariwisata.

3. Pelaksana melaksanakan tri dharma perguruan tinggi.

4. Pelaksana membantu program kerja pemerintah untuk meningkatkan pariwasata pedesanaan melalui pelatihan pemasaran dengan teknik convert selling untuk produk pariwisata.

5. Pelaksana berhasil melakukan PkM dalam jumlah peserta yang terbatas sebagai tolak ukur untuk melakukan PkM yang lebih besar.

\section{REFERENSI}

BPS., (2019). Jumlah Kunjungan Wisatawan Nusantara, $2015 \quad-2018 . \quad$ https://www. bps.go.id/dynamictable/2019/09/24/1645/jumlahkunjungan-wisatawan-nusantara-2015---2018.html/

Muganda, M., Sahli, M. and Smith, K. 2010. Tourism's contribution to poverty alleviation: a community perspective from Tanzania. Development Southern Africa. Vol 27. No 5, pp.629-646. DOI: 10.10800376835X.2010.522826.

Prasiasa, D. 2013. Destinasi Pariwisata Berbasis Masyarakat. Jakarta: Salemba Humanika. 